\title{
Post-conflict women's movements in turmoil: the challenges of success in
}

\section{Liberia in the 2005-aftermath*}

\author{
PETRA DEBUSSCHER AND MARIA MARTIN DE ALMAGRO
}

University of Antwerp, Lange Nieuwstraat 55, 2000 Antwerp, Belgium

Université libre de Bruxelles, Institut d'Etudes Européennes, F. Roosevelt 39, 1050 Bruxelles, Belgium

petra.debusscher@uantwerpen.be

$\underline{\text { mmartind@ulb.ac.be }}$

ABSTRACT In Liberia, women's advocacy has been crucial in bringing peace after 14 years of conflict as well as in electing Africa's first female president. While the accomplishments of the women's movement have been praised widely, some authors have suggested that the once vibrant movement is crumbling. In this article we claim that one of the most important challenges for the Liberian women's movement comes precisely from its internationally proclaimed success, provoking four related outcomes: First, different women's organisations compete for the credit of the success story; second, the national government has tried to appropriate the movement and integrate it into governmental structures; third, the movement's relationship with its international partners has evolved towards mutual disappointment; due to the lack of sustainable funding mechanisms and unmet expectations on the donors' side; and fourth, the movement seems stuck in the peacemaker labels unable to redefine itself to engage in new battles as international aid diminishes.

Liberia, a small West African country, experienced a brutal civil war between 1989 and 2003 involving 'near statelessness, horrific warfare and warlord terrorism' (Moran 2009: 1). After

\footnotetext{
* The authors are grateful to the editors of JMAS for their valuable input and to the critical and insightful comments from three anonymous reviewers. The authors also thank the Research Foundation - Flanders (FWO), the Fondation Wallonie-Bruxelles Internationale, the Fondation Van Buuren et the Fondation De Meurs for providing the funding that enabled this research.
} 
14 years of conflict Liberia was left with a devastated economy, infrastructure and institutions and - not least - a gravely traumatised population. However, without downplaying the harsh material realities and dramatic demographic changes, several Liberian activists have reported that the 'war has helped gender equality', as women have taken new roles ranging from 'becoming breadwinners and carrying the family' (Scott 2011 int.), to combatants, peace activists and negotiators. The Liberian conflict seems to have generated a remarkable level of collective female activism both during and after the war. Despite being victims of grave and systematic gender-based crimes, women found ways to organise themselves against (genderbased) violence and advocate for peace with 'an extraordinary level of persistent determination' (Fuest 2008: 213). Several authors agree that women's tireless activism has been invaluable to the peace process and in bringing an end to Liberia's civil war (Kellow 2010; Fuest 2009). During the subsequent period of post-conflict recovery, women's organisations came again to the forefront, leading a mass awareness-raising campaign to promote nation-wide voter registration and encourage women's participation in all aspects of the first elections after the war. When Ellen Johnson-Sirleaf was elected president in 2005, her election was seen as 'a display of solidarity among women voters in the presidential runoff vote', as well as a major victory for gender equality in Liberia (Kellow 2010: 11). In her inauguration speech, Johnson-Sirleaf expressed her 'passion and commitment to gender equity' and pledged to 'empower Liberian women in all areas of ... national life' (JohnsonSirleaf 2006). Despite this, observers have put forward serious concerns about the government's ability to improve the majority of Liberian women's lives as the government operates in a male-dominated arena with a high degree of resistance towards a more gender equal society (Masaquoi 2007). While one third of Johnson-Sirleaf's cabinet is female, the legislature and the judiciary are still predominantly male and strongly resist a decrease in male power. Although researchers and commentators have been generally optimistic about the 
achievements of the women's movement in terms of conflict resolution, political representation and policies on gender-based violence (Bauer 2009; Kaufmann 2011; Kellow 2010; Medie 2013; Pedersen 2010; Disney \& Reticker 2008), some authors have suggested that the movement's strength 'seems to be crumbling' (Fuest 2009: 135) and that there are several dynamics at work countering the continuation of a vibrant women's movement in Liberia (Williams 2008). The aim of this article is to build on this emerging literature by examining, in-depth, the challenges of the Liberian women's movement through a reading of activists' descriptions of the movement in order to reveal the political subjectivities supporting the understanding of success and failure. Face-to-face, in-depth interviews with relevant stakeholders in Liberia were considered the most useful method and took place in 2011 (34 interviews) and 2013 (30 interviews). ${ }^{1}$ In this article we focus mainly on a group of people who define themselves as being either 'gender activists' or 'women's rights activists' and hold, or have held, leading positions within a variety of (inter)national NGOs and government institutions. All interviewees were offered anonymity, which was preferred by most respondents. In what follows, we will first briefly discuss the women, conflict and NGO literature to better understand the connection between the international and the national level, as this will provide a useful framework for analysing and comparing current challenges of the women's movement in Liberia. Next, we will sketch the history of the Liberian women's movement, before delving into an in-depth analysis of the challenges met by the Liberian women's movement after 2005. After examining two sets of challenges - the first two common to other post-conflict settings, the second two specific to the Liberian case - we conclude the most important challenge for the Liberian women's movement comes precisely from its internationally proclaimed success and suggest an agenda to overcome the current standstill of the movement and avoid similar deadlocks in other contexts. 


\section{CONFLICT, GENDER AND THE WOMEN'S NGO SECTOR}

Women's organisations have expanded exponentially in Africa since the early 1990s and have taken advantage of new political opportunities brought by international aid for reconstruction and after the fall of dictatorial regimes (Tripp 2005). Largely inspired by the UN's intention to promote greater involvement of NGOs in World Summits (Otto 1996, 2009; Clark, Friedman \& Hochstetler 1998: 6; Weiss \& Gordenker 1996), many local women's groups started to establish connections with international NGOs as potential avenues for advancing their cause internationally (Basu 1995). Although the majority of the groups were inexperienced in international advocacy, their participation in these summits and collaboration with feminist NGOs based in the North, allowed many to realise new means through which to influence their governments' reports to the UN and to lobby for changes in international norms (Alvarez 2000, 2009). Therefore, the development of women's peace activism was strongly linked to the support of international organisations, which in the last decade have promoted Resolution 1325 and the Women, Peace and Security Agenda as the main framework for including gender equality in international military and security affairs. The Resolution urges member states to integrate gender perspectives on peace and security issues, recognising that women experience conflict in a specific way and stressing women's rights to contribute to conflict resolution and peacebuilding (Shepherd 2008; Pratt \& Richter-Devroe 2011; McLeod 2011). Part of Resolution 1325 calls for actions to be taken by actors within the UN system and UN missions in post-conflict settings in order to develop 'effective institutional arrangements' that guarantee women's participation in peace processes as this would help to maintain peace and security in the country (Hudson 2010). The underlying expectation is that women who join negotiations will automatically conform to the image of 'brave and tireless women who... share the ability to see beyond national boundaries, even while their governments maintain isolationist or pro-war positions' (Rehn \& Sirleaf 2002: 75). 
Feminist scholars have, therefore, criticised the Women, Peace and Security Agenda pointing out its tendency to support an essentialist women's role in the reconstruction process, which associates peace with traditional female roles such as mothers and mediators (Porter 2007; Reardon \& Asha 2010), while at the same time defining women as victims of war who are in need of protection (Pratt \& Richter-Devroe 2011; Charlesworth 2008: 351; Kouvo \& Levine 2008; Skjelsboek \& Smith 2001). Feminist scholarship has stressed the need to overcome the status of women as victims or pacifists in order to transform unequal gender relations and achieve social justice and equality (Shepherd 2011; Tickner 2001; Caprioli \& Boyer 2001).

In order for women to show how they are more than victims, African feminist scholars have argued that women's grassroots activism in Africa has contributed to informal peacebuilding and that this has been recognised in the policy arena with the establishment of national legislation on gender equality (Mazurana et al. 2005; Cockburn 2007; Tripp et al. 2008). However, these successes are watered down by the fact that women have not been part of formal negotiation processes as peace negotiators and political decision-makers as these processes typically remain deeply masculine (Korac 2006; Hudson 2009). Indeed, critics highlight the fact that national women groups are employed by international organisations and donors as useful local partners for implementing peacebuilding and reconstruction projects, but not as activists with an independent voice advocating for women's rights (Hudson 2010; Martin de Almagro 2015). For these scholars, two consequences result from this understanding: First, women's grassroots efforts are seen by many local governments as either in opposition to the government or as implementers of governmental policies. Second, as countries move beyond a post-conflict period and donor priorities change, women's grassroots activism needs to reinvent itself in order to survive (Swaine 2010; Hudson 2013). In the next section, we briefly sketch the recent history of the Liberian women's movement in 
order to highlight its complex relationship with the national government and the international community.

\section{THE LIBERIAN WOMEN'S MOVEMENT: A SHORT HISTORY}

From the beginning of the war, numerous women responded to the basic needs of their affected communities. Subsequently, women began to join together to develop relief organisations and played leading roles in providing support to displaced people and waraffected communities (African Women and Peace Support Group 2004). These groups were not limited to one particular class or county and 'existed at all levels from the most powerful urban elites to illiterate villagers' (Moran \& Pitcher 2004: 504).

In February 1994 several women's organisations joined together under the banner of the Liberian Women's Initiative (LWI). This marked the beginning of a Liberian women's political movement and many years of peace advocacy would follow. With the overall objective of disarmament, the initial activities of the initiative were focused on networking with senior diplomats and UN officials both inside and outside of the country, as well as on mediation efforts between the warring parties (Massaquoi 2007). As a result of this advocacy work, the 1995 Abuja peace agreement encapsulated several of LWI's key concerns including the encampment, disarmament and demobilisation of all combatants and the call for a special election to establish a new democratically elected government (Moran \& Pitcher 2004).

However, the newfound peace would turn out to be temporary as it led to the election of warlord Charles Taylor, who proceeded to ignore the provisions from the Abuja agreement (Moran \& Pitcher 2004). During the brief and instable period of reconstruction, women's peace organisations gained a high degree of credibility and their role in the peace process 
attracted the attention of external funding agents. This injection of funding gave many organisations new opportunities, but within the framework provided by the donors (African Women and Peace Support Group 2004; Moran and Pitcher 2004). It was precisely this international framework, closely linked with the Women, Peace and Security Agenda, that branded these grassroots women's organisations with the label of peacemakers and the expectation that they would maintain the peace and security initiatives given the provision of funding and capacity building (Olonisakin, Barnes \& Ilpe 2011; Shepherd 2008).

Although the war officially ended in 1997, violence continued and expanded regionally as the Taylor regime supported armed rebels in neighbouring countries, resulting in those states sponsoring Taylor's opponents. In 2000, this prompted peace activists from Liberia, Sierra Leone and Guinea to come together under the banner of Mano River Women's Peace Network (MARWOPNET), in a meeting organised by the international NGO Femmes Afrique Solidarité and supported by the African Union, the African Economic Community, UN Development Programme and the Nigerian government (MARWOPNET website). This network, consisting of 'elite professional women', was funded by the international community and brought together diverse networks operating in the region, such as the LWI, to advocate for peace in the affected West Africa countries (Femmes Africa Solidarite 2011; Moran \& Pitcher 2004: 508).

In 2001 in Liberia, Taylor's armed faction was violently confronted by a new group of rebels. Against this background, a new generation of female peace demonstrators joined the old and the Liberian Women in Peace-building Network (WIPNET) was founded. The network's peace advocacy went beyond the cessation of violence during war to include the termination of structural and systematic gender-based violence in everyday society as 'expressions of a deeper systemic disregard of women' (Gbowee 2009: 1). The organisation, funded by 
international organisations and acting as a member of the international network Global Network for Women Peacebuilders - with direct access to the UN Committee on the Status of Women (CSW) sessions - recruited widely from all levels of Liberian society, including hundreds of women from refugee camps near Monrovia.

However, when the Accra peace conference started in June, MARWOPNET was the only women's organisation that had received accreditation to participate in the negotiations. The organisation justified its inclusion in the peace talks by explicitly referring Resolution 1325 on Women, Peace and Security (Fuest 2009). Other women's groups, such as AFELL, participated as observers, while others were present in Accra to put pressure on the negotiators. A delegation of WIPNET travelled to Ghana and mobilised Liberian women living in refugee camps to demonstrate for peace in front of the conference site. The multitude of actions by women peace advocates both inside and outside of the conference room were not without effect. The Liberian Peace Agreement - signed on August $18^{\text {th }} 2003$ - contained some remarkably gender-relevant policies (Fuest 2008). For example, the agreement stipulated that women should be included in the Governance Reform Commission and the National Elections Commission, and that the National Transitional Legislative Assembly should include members from women's organisations. Additionally, article XXVIII of the agreement, dealing with national balance, contained a remarkable exception compared to other peace agreements (Fuest 2008) as it stated that the transitional government of Liberia 'shall reflect national and gender balance in all elective and non-elective appointments' (Government of Liberia, LURD, MODEL and Political Parties 2003). Such references are atypical when compared to similar peace agreements and are to be attributed to women's advocacy. 
In the run-up to the first post-conflict elections in 2005, women's groups supported over 100 female candidates, including two candidates for the presidency and four for the vicepresidency (Kellow 2010). Furthermore, women's groups led a mass awareness campaign to encourage women to register and vote, which resulted in a higher female than male turnout. When Ellen Johnson-Sirleaf, a US-educated bureaucrat, came out against former soccer star George Weah in the run-off, women's competing loyalties were set aside (Bauer 2009). During the election campaign, activists wore t-shirts reading 'All the men have failed Liberia; let's try a woman this time' (Massaquoi 2007: 30). Or as put by an activist closely involved in the campaign:

'In 2005 we have gone round to encourage women to vote for madam Sirleaf. The women's movement played a critical role. They felt at that time that the women had suffered more and that the men where the main perpetrators. Beyond party lines they voted for Ellen. They wanted change and security' ('A', 2011 int.).

The consolidated support for women's participation in the electoral process was not without results and on 8 November 2005, Weah was overwhelmed by Sirleaf who received more than 59 per cent of the votes. Sirleaf's election was seen as a breakthrough for gender equality (inter)nationally as she became the first elected female head of state in Africa. After Sirleaf's historic victory, her supporters 'filled every street corner' in Monrovia singing 'Women, this is your time!'(Massaquoi 2007: 30). While the euphoria at the time was breath-taking, the question remains at to whether or not activists have been able to capitalise on their success and improve the situation of women in Liberia since 2005.

As a matter of fact, on 7 October 2011, WIPNET founder Leymah Gbowee, along with Liberia's president Ellen Johnson-Sirleaf, were named winners of the Nobel Peace Prize 'for their non-violent struggle for the safety of women and for women's rights to full 
participation in peace-building work' (Norwegian Nobel Committee 2011). As the announcement came just four days before the presidential vote, it was seen by major opposition politicians and their supporters as a 'provocative interference'2 in Liberian politics. Although Johnson-Sirleaf was re-elected with 90.7 per cent, the turnout was low - 38 per cent as compared to the 71.8 per cent turnout in the first round. A year later, Gbowee sharply criticised the president and resigned from a government post, for not doing enough to combat poverty and government corruption and cited 'differences in opinion on the pathway for national healing and reconciliation'. ${ }^{3}$ This public sign of discord between the two powerful women shows that civil war-related tensions and divides are lingering and impacting the women's movement. In the next section we will delve into analysing the challenges encountered by the Liberian women's movement in the post-2005 period.

\section{DISENTANGLING THE CURRENT CONTRADICTIONS IN THE LIBERIAN WOMEN'S MOVEMENT}

In October 2011 the second presidential and parliamentary elections took place since the end of the civil war. While President Johnson-Sirleaf was convincingly re-elected for a second term, women's participation in both chambers did not rise and even experienced a slight decrease, from 12 to 11 per cent of seats, or 11 out of 103 seats (Inter-Parliamentary Union 2011). Several gender activists pointed out that the situation was not as favourable as in 2005 when the women's movement support was crucial to make sure women took part in the elections and secured women's victory. For many activists in Liberia, the peacebuilding process was not based on an identification with feminist ideology or on innate feminine impulses but, as El Bushra observes elsewhere, 'on a pragmatic response to desperate situations rather than on an inherently pacifist orientation' (El Bushra, 2007: 135). As one Liberian gender advocate put it: 
'After the war we had a strong women's movement. Now it has broken apart. Everyone is in different places. There is no more advocacy. We have NGOs and CBOs in thematic areas, but no women's movement. In the past there was the advocacy on the rape law and on the property law, now... there seems to be no common ground ... We should all be working on increasing women in decision making!! It's not as in 2005... In 2005 there were messages all over the place and in media. I don't see any banners... The momentum is not there' ('B' 2011 int.)

It seems that the determination and unity of the women's movement that was built up during the war years has diminished (Fuest 2008). In what follows we discuss two types of developments explaining the weakening of the women's movement after 2005. First, we discuss developments common to women's movements in post-conflict settings, that is, internal cleavages (Hebert 2005) and unstable relationships with international partners due to a lack of ownership and sustainable funding, similar to other cases such as in Burundi, Democratic Republic of Congo (DRC), Namibia or Sierra Leone (Martin de Almagro 2015; Becker 2003; Kim \& Campbell 2013; Puechgirbal 2004). Second, we examine developments more characteristic of the Liberian case, such as the appropriation of the movement by the national government and the impossibility of overcoming the label of agents of peace conceded to the movement. We argue that these developments are a product of its internationally acclaimed success that came hand-in-hand with the consequent flow of financial contributions, media attention and publicity. We acknowledge that in arguing this way we have left behind the analysis of challenges to the women's movement inherent to local societal structures in post-conflict contexts (Cockburn 2002; Tripp et al. 2009). ${ }^{4}$ However, the aim of this article was to highlight the particularities of the Liberian case regarding local relations with the international community which involve specifically, the pervasive effects of the Liberian women's movement's international popularity on the internal dynamics of the women's activism? 
Since the women's peace movement was founded in 1994 by educated, professional women, there have been tensions between 'uneducated/county women' and 'educated/Congo women' (Fuest 2009: 132). According to Ellis and van Kessel, the Liberian women's movement has been dominated by women from the country's elite, situated 'at the juncture of Liberian society and its external links, most notably with the US' (2009: 7). Although all major women's groups have made efforts to embrace women from all ethnic, religious and socioeconomic backgrounds, to some extent, it seems that uneducated women have been 'instrumentalised by their leaders', as it was not elite women who were reported to be sitting on the airfield and 'praying in the rain and sun for hours' to demonstrate for peace (Fuest 2009: 119, 132).

According to Williams, conflicts between elite 'civilised' women and uneducated poor (rural) women as well as between younger and older generations are key drivers of the women's movement's lack of vibrancy (2008: 45). In a 2009 interview with Voice of America, WIPNET founder Leymah Gbowee explicitly explained the tension between MARWOPNET and WIPNET as a generational and a social class issue (Pedersen 2010):

We avoided linking up with MARWOPNET because we felt they had never bothered to carry us along - their generation. They were doing their work exclusively amongst their age and social class group. So we thought, okay, we'll start our own thing... The older women had their efforts, and we younger women had ours. We are trying to bridge this gap, but it's hard given that most young women aren't educated. We want to engage with the girls, so that they don't feel hateful towards us, as we felt hateful towards the women who were older than us. $^{5}$ 
These particular cleavages were also visible in the disputed readings of history that came forward during the interviews, as some activists down played or kept silent on the role of other key activists or organisations during the peace process while overemphasising their own role. The 2008 documentary Pray the Devil Back to Hell, which depicted the role of the women's movement in ending the country's 14-year civil war is a good example of this. The award-winning documentary only contains interviews with the Christian Women's Initiative and WIPNET - organisations that were excluded from the peace talks in Accra - and shows footage of their sit-in in the conference hall, while it is silent on the role of MARWOPNET, whose members were negotiating inside the conference room, as well as on the role of organisations such as AFELL or LWI. During several interviews it became clear that this partial image has been met with great discontentment by certain groups.

Since the most pressing need for cooperation has ended, it seems that societal structures and divisions of class, religion, ethnicity and age have come to the forefront again, following similar patterns of women's movements in other post-conflict settings (Hebert 2004; Cockburn 2007; Mojab 2009; Kim \& Campbell 2013). Due to the dizzying variety of women's organisations, the high poverty and unemployment rates and the limited amount of funding, there is significant competition among women's organisations. Several women's rights activists feel the women's movement has become increasingly competitive and reported that the movement is plagued by a 'crab mentality'. ${ }^{6}$ According to one interviewee, the successes of the past and lack of cohesion in more recent times can be attributed to a different communication style in the post-conflict period, as having a voice in the movement has become progressively more exclusive. Or as she put it:

'You can only have a women's movement when there is a cohesive continuous dialogue process. ... We need to listen to one another, we need to understand why am I taking the stand I am taking....those in leadership assume that they know it all. They have all the answers. ...Do you know why the women's 
movement was successful during the war years? Because when we sat on the field everybody was consulted and given proper opportunity to give opinion on what it is we are going to do. And those opinions where drawn from the women in the field. The ones in decision making positions took this information and tried to see how they could work with it. But it's no longer being done'('C' 2011 int.).

This seems to be confirmed when taking into account the advocacy process for the Gender Equity Bill. Since 2009 the Women's Legislative Caucus, a group of women parliamentarians across party lines, have been promoting a Gender Equity Bill with the aim of introducing a quota system of 30 per cent reserved seats for women in politics. UNWOMEN supported and sponsored the process and only in a later stage was AFELL brought in to participate in the meetings and facilitate the dialogue with the Senate and the House. However, in March 2011, the bill was presented to the Senate and denied for the second time. The reasons attributed to its failure vary from weak argumentation over a sexist male dominated legislature to a confusing proposal receiving 'little support from the civil society' ('D', 2011 int.). ${ }^{\dagger}$ Several gender advocates, however, point out that the proposal was rejected because the process has been elite-driven and because broader consultation with women's groups as well as with common men and women across Liberia was lacking. Consultation processes and communication styles are indeed connected to social class divisions. As noted by Yarrow, 'rhetorical skill is an important aspect in the consolidation of status and identity in a variety of West African contexts' (2008: 338), including Liberia, and can serve as either an including or excluding force.

In Liberia, there has been 'no forward looking vision to transform the peace activism into political activism' (Williams 2008: 45) and, unlike in the past, effective communication and consultation mechanisms to bridge differences and reach a common political position have not been effected. As a more pessimistic respondent puts it:

\footnotetext{
$\dagger$ Interview representative international donor organisation, 28 June 2011. Olga De Biachio
} 
'There is no women's movement, it is a crisis movement. Women move together whenever there is a crisis. There is no real process of continuity. Women will get involved together whenever there is an urgent need around violence. But in the sense of maintaining that cohesion... It's very difficult.' ' $C$ ' 2011 int. voice of voiceless).

\section{Relationship with international partners: unsustainable funding policies and unmet} expectations

As with women's movements elsewhere (Alvarez 2009; Basu 2000), a second explanation for the weakening of the Liberian women's movement can be found in the evolution of its relationship with international partners and the available funding mechanisms that come with it.

Several activists who were interviewed mentioned problematic issues regarding funding modalities. One difficulty relates to the general duration of projects and collaborations. Most local calls for projects are short-term (e.g. six months to two years) and limited in funding, and so do not allow organisations to engage in longer-term planning or conduct more time intensive projects as they seldom offer instantly measurable results. Furthermore, some advocates felt that because of the strict bureaucratic setup, including short timeframes and short-term deliverables, the projects are too focused on reactive measures as supposed to being preventive. As one gender activist put it:

If donors say that, then everybody runs into that area. It's not sustainable. It's not holistic. If the money is too tiny you can only do this or this. Nothing substantial with a deeper vision. ('E' 2011 int.)`

\footnotetext{
$\$$ Interview gender advocate working for a Liberian nongovernmental organization, 4 July 2011, Monrovia.voice o voiceless

$\S \underline{\text { Rosana }}$
} 
Several larger Liberian NGOs reported feeling used by INGOs to implement their agendas without any guarantees for the longer-term survival of their organisation. Some interviewees connected the lack of sustainable funding and ownership to the sustainability of peace in Liberia.

‘...how will these isolated projects ever build the capacity. There is no real ownership. We cannot even talk about accountability. We should not be here... After what we have done for our country. We go from project to project and can barely pay our rent. There is no sustainability. My personal vehicle broke down so now [well-known Liberian women's organisation] doesn't have a vehicle. They [INGOs] use your facilities to get their objectives and you depend on their agenda. Where is our ownership? Is this continuing peace? It is fragmented because of the short term funding we get. Peace building is not a long term thing here.'. ('F' 2011 int.) ${ }^{* *}$

Additionally, the requested projects rarely involve capacity building. Some gender activists are worried about what will happen when the international community leaves, as many INGOs do not build the skills and capacity of local organisations. In some instances, INGOs are even temporary pushing the local organisations aside.

'Take for example the influx of refugees from Ivory Coast. Local organisations have been working there since December [2010] providing for refugees with the little resources they have, searching for accommodation in the houses of volunteering families. They know the area, the language and its people. Then in March [2011] the big NGOs came, building huge camps and crowding out the smaller organisations that have been working there for months. I strongly feel they should work with the existing organisations and invest in building their capacity. They have to build our capacity, because

\footnotetext{
*** Interview gender advocate working for a Liberian nongovernmental organisation, 21 June 2011, Monrovia. cesaer
} 
they are not going to remain! You never know when they will arrive and when they will leave again.

Often they don't even know themselves' ('E' 2011 int.) H'

Another problematic aspect is that the projects requested by international organisations are very much focused on service delivery and barely allow organisations to get involved in research, policy monitoring or advocacy. The specific content of the activities demanded by donors and international organisations is pushing Liberian women's organisations into an unsustainable and ad hoc service delivery role ('B', 'F', 'G' 2011 int). Or as one respondent put it:

'It is not sustainable in any way. The movement can only work when it has funding. They are so busy trying to keep afloat that they don't have time for government issues... For example, giving a press conference? No money.' H' ('G' 2011 int. Deola)

Almost all gender advocates who were interviewed indicated that they encounter more and more difficulties in accessing sustainable funding for their organisations, as applying for larger or longer term funding is subject to strict financial and bureaucratic conditions (e.g. pre-acquired financial capacities and previous experience in international projects). Furthermore, proposal writing is a time-consuming process which requires women's advocates to use a certain professional language to which donors can relate and fit their proposed initiatives into successful aid industry formats (Debusscher 2014). Most Liberian NGOs applying for bilateral donor funding go into partnership with a leading INGO, as many respondents reported that receiving funding directly from bilateral donors, such as the European Union or USAID, seems to be 'impossible.' ${ }^{7}$ At times INGOs and Liberian NGOs compete for the same funding. However, in competition between professionalised INGOs and

\# Interview gender advocate working for a Liberian nongovernmental organization, 24 June 2011, Monrovia. Mrs Rosana Schaak, THINK Liberia

\# Interview gender advocate working for a Liberian nongovernmental organization, 27 June 2011, Monrovia. Deola 
less professionalised Liberian NGOs, the latter are usually on the losing side. Also, a 'partnership' generally means that the INGO is the leading and deciding partner. The system implies that the broad priorities of development are driven by international donors because 'they decide whether it is HIV/AIDS or gender-based violence' $\S \S$ that is important for gender equality in Liberia ('E' 2011 int.). Although it would be a mistake to see the relationship between international sponsors and Liberian NGOs as a one-way-relationship, as the latter are often creative in bridging their interests with those of donors, the unequal partnership 'may lead organisations to adjust their programmes, agendas and agency' (Kaufmann 2011: 167) in the interest of sponsorship. The Liberian gender advocates' agenda may, therefore, be compromised by dominant development paradigms as the funding practices of donors and INGOs are geared towards the peacebuilding business. As donors and INGOs rely on their own understanding of 'what constitutes a 'legitimate' local NGO' (Moran \& Pitcher 2004: 509), as well as what they believe to be the appropriate actions to enhance gender equality in Liberia, Liberian NGOs' room for manoeuvring shrinks as their agendas often go through a double filter - first of the donor and second of the INGO. The result is that a Liberian NGO that wants to survive needs to use 'the discourse necessary to attract the support of external patrons' (Moran 2009: 23). Unfortunately, dominant development paradigms and practices brought by expatriates from other (post-conflict) settings are not necessarily relevant in present day Liberia and create an oversimplified or even counterproductive picture of gender relations in Liberia ('H' 2011 int.). ${ }^{* * *}$ In this context it is useful to refer to Abramowitz and Moran's recent work in which it is demonstrated that 'despite the tremendous international investments' in gender-based violence initiatives, 'gender violence as defined by global institution continues to be rampant', as international and national NGOs 'have defined

\footnotetext{
$\S \S$ Interview gender advocate working for a Liberian nongovernmental organization, 24 June 2011, Monrovia. Rosanna

*** Interview gender advocate working for an international nongovernmental organization, 6 July 2011, Monrovia. Williams
} 
Liberia's agenda on gender-based violence without reference to local populations' definitions of gender subordination, exploitation, and abuse' $(2012: 128,131)$.

\section{Relations with the State: women's associations as implementers}

A related source of tension that came forward during the interviews is the degree of access to the government. Interviews revealed that some organisations have direct access to government institutions and officials, and seem to have easier access to funding mechanisms. As one interviewee put it, 'because they [the government] have the pipe, they select who dances to the tune.'('I' 2013 int.) $)^{\text {tit }}$ Interviews showed tension between those who are part of or have access to the government and the legislative, and those who do not have such access. Access to and voice in the Ministry of Gender and Development and its related institutions, such as the Gender-based Violence Task Force, seemed to be on an ad hoc and personalised basis, 'rather than based on institutional relationships between society and the state in which individuals and groups can demand access to rights as citizens' (Gready 2010: 642). Along this line, some interviewees complained that the Ministry of Gender has attempted to dominate the gender-based violence conversation and the activities of all organisations, showing favoritism towards some NGOs and marginalising others who express dissenting views (' $\mathrm{J}$ ', ' $\mathrm{K}$ ' 2013 int.). + tt This has created resentment amongst some advocates and hindered the extent to which they have shared ideas and information with other organisations, particularly with international NGOs. However, for gender equality policies to be transformative, such 'ad-hoc government-civil society interactions are not sufficient'

\footnotetext{
\#I Interview with the president of a national women organisation in Monrovia, Liberia, 5 September 2013 maria + Interview, female member of staff of Liberian NGO, Monrovia, August 2013; Interview, female member of staff of Liberian NGO, Monrovia, 2 September 2013 Maria
} 
(Debusscher and Ansoms 2013), and structured mechanisms and fora where permanent collaboration can take place on an equal footing are needed.

Unlike the past, Liberia's present gender equality policy seems to be the result of intense cooperation between government, the UN, donors, the international community and certain civil society actors. Indeed, once the national government realised the potential of civil society to attract funding and to develop projects and programmes for the implementation of public policies, it started considering civil society organisations as implementers of governmental politics and as technical experts rather than as a counter-balance of its policies and politics ('L' 2013 int.) ${ }^{\S \S \S}$. In practice, this means that women's organisations leave their political agenda behind and collaborate with governmental structures to execute projects on "women issues" for which international funds and assistance have been deployed. One of our interviewees reminded us of the fact that "the government works directly with WONGOSOL and has a de facto power of choosing the organisation and the individuals they will work with

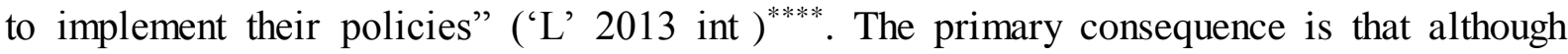
there is a lack of trust and tensions, both parties know they need each other, particularly when it comes to accessing funding and gaining international attention. However, with the exception of a few women's organisations, civil society's gender activists seem to be largely side-lined in the debate on the promotion of gender equality in Liberia. Several important women's groups complained about being marginalised in strategy meetings and not getting a real voice in policymaking. Practices, such as only receiving 24 hours to give feedback on an important five year planning document on gender policy, seem to be commonplace ('H' 2011 int.). ${ }^{\dagger \dagger i}$ It was also mentioned that the utilisation of consultation mechanisms, such as the Gender-Based Violence Task Force, is heavily dominated by the UN and the Ministry of

\footnotetext{
$\S \S \S$ Interview, Secretary General of a Liberian nongovernmental organization, Monrovia, 19 August 2013.

**** Interview, Secretary General of a Liberian nongovernmental organization, Monrovia, 19 August 2013.

$\mathrm{H}$ Interview gender advocate working for an international nongovernmental organization, 6 July 2011 , Monrovia. Williams
} 
Gender and Development ('G' 2011 int.). ${ }^{+1+}$ For their part, women political leaders complain about the lack of involvement of women's organisations and blame them for not directing their concerns and suggestions to women in office (Reaves 2013 int.). ${ }^{\S \S \S}$ The executive branch of the government offers a similar type of discourse. An official working at the Secretariat for the implementation of UN Resolution 1325 at the Liberian Ministry of Gender indicated that the lack of engagement with some women's organisations is due to the fact that certain organisations are not to be trusted and that there is a lack of accountability mechanisms to ensure that funds allocated are spent according to contracts and expectations ('M' 2013 int.) $)^{* * * * *}$.

Mutual blaming and lack of collaboration are common to other post-conflict contexts (Roces \& Edwards 2010; Tripp et al. 2008; Cockburn 2007; Mazurana et al. 2005). However, in 2009 this chasm between Liberian gender activists from civil society and from the state reached a climax unseen in other countries when the Ministry of Gender and Development founded the Rural Women's Structures - a rural women's organisation with divisions in every county and a national president at the top. According to the Ministry, the new structure would allow it 'to have a better grip'('A', 2011 int.) ${ }^{\dagger+t \dagger}$ through the counties and to have better campaigning opportunities. Within the Ministry this was seen as an important advantage to bring more women to office in the 2011 elections, as 'in 2005, advocacy was mainly done by women's organisations' who 'did not have a strong hold on the women in the counties.' ('A', 2011 int.). ${ }^{H}+$ However, the founding of the Rural Women's Structures has angered several activists as they argue that there are several existing long-standing nongovernmental rural women's organisations and that the new structure 'divides rural women' ('N' 2011 int.; 'O'

$\$+\$$ Interview gender advocate working for a Liberian nongovernmental organization, 27 June 2011, Monrovia. Deola

$\$ \S \$ \S$ Interview Francis Reaves, Representative at the Liberian Congress, 2 September 2013, Monrovia.

${ }^{* * * * * *}$ Interview with a staff member of the Secretariat for the implementation of UNSCR 1325, Ministry of Gender, Liberia, 15 August 2013. maria

拉宄 Interview senior official Ministry of Gender and Development, 5 July 2011, Monrovia. Harries

Mt+ Ibid harries 
2013 int.). ${ }^{\S \S \S \S}$ What is more, activists point out that it is now impossible to get support for rural women that are not part of the Rural Women's Structures and that the existing grassroots organisations are being marginalised ('P' 2011 int.; 'Q' 2013 int.). ${ }^{* * * * * *}$ The Ministry is, therefore, very influential in deciding which organisations survive and which ones are condemned to disappear because of a lack of funding. Moreover, the Ministry also appoints the local leaders of the Rural Women's Structures in Liberia's 15 counties (Minister DuncanCassell 2012: 2), This has drained the existing rural grassroots groups, taking away the few skilled leaders they had. In 2010, several of these organisations joined a Coalition of Civil Society Women in Liberia to protest against the 'go-it-alone' Ministry and the founding of the Rural Women's Structures. The issue was brought to the level of President Johnson-Sirleaf, and senior gender activists tried to mediate between the Coalition and the Ministry, but without effect ('N' 2011 int.). The result is a tense situation where loyalties based on gender are fading and where the cohesion of the movement is becoming more compromised. The following testimony from a Liberian activist now working for an INGO complements this finding by pointing out that the international community which is supporting the Rural Women's Structures is, in fact, prolonging this rift while not generating real impact on the ground:

'The whole Rural Women thing has become a political organisation, highly political. That's true, you have a lot of international organisations helping them ... [However] the funding or the work with them is not producing any resource. I haven't seen any real impact ... of the work that has come from UNWOMEN all over the years ... I haven't seen it. Women are still on the same spot in Liberia. '( 'R' 2013 int.)

\footnotetext{
$\$ \$ \$ \S \S$ Interview gender advocate working for a Liberian nongovernmental organisation, 6 July 2011, Monrovia; interview with the leader of a local rural women association in rural Montserrado, 8 August 2013. Participant observation in an internal meeting of a Liberian women's organisation, 7 July 2011, Monrovia.

${ }^{* * * * * *}$ ECOWAS and Interview with the president of a small organisation in rural Montserrado called Rural Women of Liberia, 7 August 2013 Maria

it+tit Interview with the President of a national women association, Monrovia, 3 September 2013 maria
} 
The interviewee highlighted the politicised nature of the Rural Women Structures pointing to the fact that its leaders are appointed directly by the government and priorities are determined by the Ministry of Gender and Development. According to the interviewee, this is the reason why, even if a lot of national and international resources and efforts have been put into it, there have been no results. Indeed, as put by Weldon, if the feminist movement is too contained by the state, its ability to 'challenge the existing order of priorities' and draw attention to issues that are not on the agenda, may be curtailed (2012: 37).

\section{Trapped in the peace-maker label}

As in other contexts, Liberia non-governmental organisations often 'adjust their programmes, agendas and agency' (Kaufmann 2011: 167) to the interest of sponsors, and hence become compromised by dominant development paradigms. Since the end of the civil war and the need to implement the UNSCR 1325 and the Women, Peace and Security Agenda, donors in Liberia have been 'overwhelmingly focused on sexual violence' (Shepherd 2008; Olonisakin, Barnes \& Ilpe 2011), and more specifically on rape. This has created a situation where other forms of gender-based violence, such as domestic violence (Medie 2013: 391) as well as its economic and structural causes (Abramowitz \& Moran 2012) have been mostly ignored. On this agenda, Liberian NGOs have turned out to be the perfect partners, as soon they have learnt to consciously use their identity of victims of war in need of protection (Pratt \& Richter-Devroe 2011; Charlesworth 2008; Kouve \& Levine 2008) and of 'brave and tireless women' and peacemakers (Rhen \& Sirleaf 2002:75), with which they have gained the attention of media and donors - most notably after the Mass Action for Peace movement was displayed in the documentary Pray the Devil Back to Hell. 
Under the framework of the agenda on Women, Peace and Security and the need to empower grassroots women, the creation of the so called Peace Huts has been one of the biggest projects funded by UNWOMEN and several INGOs, and put in place by WIPNET, the local partner. The Peace Huts are community-led peacebuilding groups where women meet every week and try to solve problems in the community, acting as mediators in conflicts such as land disputes, rape cases or conflicts of an ethnic or religious nature. The idea of mediationthrough-women as an approach to reconstructing social relations and building civil society is naturalised through the use of Peace Huts which, as a matter of fact, are organised through the National Rural Women Structures of Liberia and, therefore, through the national government. However, the problem is that the complexity of the security situation for women on the ground is reduced or framed through concepts that resonate with global audiences and donors in order to maintain funds and media attention. What is more, other newer forms of women's activism that do not involve the peacemaker or women-as-victim label, which has been so profitable up until now, are side-lined or silenced. For example, there seems to be no campaign for the enforcement of the Liberian inheritance law, which gives equal inheritance rights to women and men. A staff member of an INGO explained that, although there have been discussions on the need to work on the issue, no organisation was doing so ('S' 2013 int.). $+1+$ This is problematic as international companies are increasingly buying land from local communities for the exploitation of mineral or agricultural resources. Most often, these local communities are represented by a local council consisting exclusively of men which (re)generates unequal outcomes for women and discrimination in decision-making. This example illustrates how coordinated post-conflict development aid supplies the language and institutional discourse for advancing a certain development agenda without challenging the 
patriarchal structures of the societies that are being "reconstructed" and how the Liberian women's movement has become absorbed in this process (Hudson 2009; 2013).

Two years after our first round of interviews, the situation in Liberia is the same: a noncoordinated women's movement trapped inside a peace heroines identity, a government suspicious of a civil society with better implementing capacities than its non-performing institutions, and disappointed international donors dealing with results that clearly do not match their previous expectations. Perhaps, as one of our interviewees explained, the problem simply has to do with perceptions and labels. Due to the political opportunity structure, at both national and international level, the Liberian women's movement has remained a crisis movement, unable to escape its limiting peace-maker label, and with little experience in other areas. This has rendered it unable to develop into a broader, coherent and professionalised movement capable of producing all-round results. As put by one Liberian respondent:

'But we have to wait here. They are recognised because of their work [on] conflict and peace and we are talking about that they stopped the war, that's what they are famous for. No one has said that they are famous for working for economic empowerment, for working for gender based violence, etc. ... how to work together... they [still] have to learn ('T' 2013 int.). '\$s\$s\$

In hindsight, too few investments have been made after the war by the international community to professionalise and develop the capacity of national civil society organisations and enable them to participate on the international arena and hold their government accountable. Indeed, although the democratic space for freedom of association and speech has opened up after the war, civil society has not yet had the opportunity to develop the new skills needed to realise this responsibility.

\section{DISCUSSION AND CONCLUSION}

$\S \S \S \S \S$ Interview staff from INGO country office in Monrovia, Liberia, 10 August 2013 
The aim of this article was to contribute to the literature on women's movements in postconflict settings in Sub-Sahara Africa through an in-depth examination of the challenges encountered by the Liberian women's movement after 2005. We claim that one of the most important challenges for the Liberian women's movement comes precisely from its internationally proclaimed success. We assert that the extraordinary success of the movement has provoked four related outcomes. First, the different women organisations compete for the credit of the success story; second, the national government has tried to appropriate the movement for itself and to integrate it into governmental structures through the Rural Women Structures of Liberia; third, the movement's relationship with its international partners has evolved towards mutual disappointment due to the lack of sustainable funding mechanisms for Liberian women's organisations and unmet expectations on the side of international donors; and fourth, as the women's movement accepted the identity label of peacemakers in exchange for the influx of international funding and support, the movement is unable to redefine itself in order to engage in new battles as international aid on peace building and reconstruction diminishes. Following the line of past research, this article showed that, since the end of the war, internal divisions based on social class, age, religion, ethnicity and location have come to the forefront within the women's movement now that the most pressing need for cooperation has been lifted. These include cleavages between educated/'civilised' and uneducated/'traditional' women, between younger and older women, and between those who have access to the government and those who do not have such access, particularly since the creation of the Rural Women Structures of Liberia by the Ministry of Gender.

The combination of internal division, restrictive funding policies, inadequate financial resources and a high poverty level are weakening the women's movement's ability to seize the momentum for gender equality in post-conflict Liberia and to overcome the label of peacemakers, which was embraced in exchange for much needed international funding and 
support. Unless the structure of political opportunities shaped by the government and the international community becomes more inclusive, the Liberian women's movement will remain a crisis movement, while its impact and cohesion are under serious threat. To overcome the current stasis, both the international gaze as well as the Liberian women's movement's ambitions need to be broadened. Internationally, more efforts should be made to professionalise and develop the capacity of national civil society organisations beyond peacemaking and crisis-prevention so as to enable them to participate in the international arena and hold their government accountable. Nationally, the women's movement needs to become more pluralistic in the kinds of issues it takes up, as well as in its internal makeup. In this sense it is crucial that women and their organisations of different backgrounds (e.g. taking into account connections between gender and class identities and/or between gender and ethnic identities), experience (more established and young organisations) and issue areas (for instance organisations working on women's employment, but also broad multi-issue organisations) can take full part in the debate on gender (in)equality in Liberia. Such diversification of the movement would certainly make it more difficult for the national government to control its agenda and funding while a stronger independence of women organisations would in turn guarantee an enhanced legitimacy and authenticity. As civil society and, in particular women's organisations, are seen as essential partners for postconflict reconstruction, the lessons learnt from this case prove useful to future efforts in other contexts. Taking an inclusive and pluralistic approach to including women in peacebuilding and post-conflict reconstruction will not only enhance the quality of the issues that are taken up, but is crucial as an empowerment strategy in itself as it creates space for non-hegemonic actors to struggle to set the gender equality agenda and move beyond the peace-maker label.

\section{REFERENCES}


Abramowitz, S. \& M. Moran 2012. 'International human rights, gender-based violence, and local discourses of abuse in postconflict Liberia: a problem of "culture"?' African Studies Review, 55, 2: $119-46$.

African Women and Peace Support Group 2004. Liberian Women Peacemakers: fighting for the right to be seen, heard and counted. Trenton, Asmara: Africa World Press.

Alvarez, S. 2000 'Translating the Global. Effects of Transnational Organizing on Local Feminist Discourses and Practices in Latin America', Meridians: Feminism, Race, Transnationalism, 1, 1: 2967.

Alvarez, S. 2009. 'Beyond NGO-ization: Reflections from Latin-America', Development, 52, 2: 175184.

Basu, A. 1995. 'Introduction', in Basu, A., ed. The Challenge of Local Feminisms: Women's Movement in Global Perspective. Boulder, CO: Westview Press, 1-21.

Basu, A. 2000. 'Globalization of the Local/Localization of the Global Mapping Transnational Women's Movements', Meridians, 1, 1: 68-84.

Bauer, J. 2009. 'Women and the 2005 election in Liberia', The Journal of Modern African Studies 47, 2: $193-211$.

Becker, H. 2003. 'Women, Politics and Peace in Northern Namibia' in Women and Peace in Africa: Case Studies in Traditional Conflict Resolution. Paris: UNESCO, SHS-2003/WS/38, 47-74.

Caprioli, M., \& M. A. Boyer 2001. 'Gender, violence, and international crisis', Journal of Conflict Resolution, 45, 4: 503-518.

Charlesworth, H. 2008. 'Are women peaceful? Reflections on the role of women in peace-building', Feminist Legal Studies, 16, 3, 347-361.

Clark, A. M., E. J. Friedman, \& K. Hochstetler 1998. 'The sovereign limits of global civil society: a comparison of NGO participation in UN world conferences on the environment, human rights, and women', World politics, 51, 1: 1-35.

Cockburn, C. 2007. From where we stand: War, women's activism and feminist analysis, London: Zed Books.

Debusscher P. 2014. 'Gender mainstreaming on the ground? The case of EU development aid towards Rwanda', European Integration online Papers, 18, 4, 1-23

Debusscher P. \& A. Ansoms 2013. 'Gender equality policies in Rwanda: public relations or real transformations?' Development and Change, 44, 5: 1111-1134.

Disney A. \& Reticker G. 2008. Pray the Devil Back to Hell [documentary]. USA: Fork Films.

Duncan-Cassell, Honourable J. 2012. 'The Empowerment of Rural Women and their role in poverty and hunger eradication, development challenges and the way forward', A presentation at the $56^{\text {th }}$ Session of the Commission on the Status of Women (CSW), New York, 28 February 2012. 
El Bushra, J. 2007. 'Feminism, gender, and women's peace activism', Development and Change, 38, 1: 131-147.

Ellis S. \& I. van Kessel, eds. 2009. Movers and Shakers. Social Movements in Africa, Leiden: BRILL.

Femmes Africa Solidarité, 'National Action Plan on the Implementation of UNSCR 1325 in Mano River Region' http://www.fasngo.org/assets/files/reports/NAP\%20on\%20the\%20implementation\%20of\%20UNSCR \%201325\%20in\%20Mano\%20River-website.pdf accessed 1.11.2011.

Fuest, V. 2008. "This is the time to get in front": changing roles and opportunities for women in Liberia', African Affairs 107, 427: 201-224.

Fuest, V. 2009. 'Liberia's women acting for peace: Collective action in a war-affected country', in S. Ellis and I. van Kessel, eds. Movers and Shakers. Social movements in Africa. Leiden: BRILL, 114-37.

Gbowee, L. 2009. 'Effecting change through women's activism in Liberia', IDS Bulletin 40, 2: 50-53.

Government of Liberia, LURD, MODEL and Political Parties (2003) 'Comprehensive Peace Agreement Between the Government of Liberia and the Liberians United for Reconciliation and Democracy (LURD) and the Movement for Democracy in Liberia (MODEL) and Political Parties', Accra, Ghana, 18th August 2003. http://www.iss.co.za/AF/RegOrg/unity_to_union/pdfs/ecowas/liberiapeace.pdf accessed 2.11. 2011.

Gready, P. 2010. "“You're either with us or against us": civil society and policy making in postgenocide Rwanda', African Affairs 109, 437: 637-57.

Hebert, L. 2005. 'Women's social movements, territorialism and gender transformation: A case study of South Africa', Paper presented at the annual meeting of the American Political Science Association, Marriott Wardman Park, Omni Shoreham, Washington Hilton, Washington, DC, 1 September 2005 http://www.allacademic.com/meta/p41242_index.html accessed on 22.08.2015.

Hudson, H. 2009. 'Peacebuilding Through a Gender Lens and the Challenges of Implementation in Rwanda and Côte d'Ivoire', Security Studies, 18, 2: 287-318.

Hudson, N. 2010. Gender, Human Security and the United Nations: Security Language as a Political Framework for Women, Abingdon: Routledge.

Hudson, N. 2013 'UNSCR 1325: The Challenges of Framing Women's Rights as a Security Matter', NOREF Policy Brief. http://reliefweb.int/sites/reliefweb.int/files/resources/4814ab8970493cca48dbbafdbb4e92bc.pdf accessed 28.01.2015.

Inter-Parliamentary Union 2011. Women in National Parliaments. http://www.ipu.org accessed 02.02.2012.

Johnson-Sirleaf, E. 2006. 'Inaugural address of H.E. Ellen Johnson Sirleaf, January 16, 2006' http://www.emansion.gov.lr/doc/inaugural add 1.pdf, accessed 23.08.2011.

Kaufmann, A. 2011. 'Mobilizing for improvement. An empirical study of a women's organization in West Point, Liberia', Stichproben. Wiener Zeitschrift für kritische Afrikastudien, 11, 20: 163-188. 
Kellow, T. 2010. Women, elections and violence in West Africa: assessing women's political participation in Liberia and Sierra Leone. London: International Alert.

Kim, E. \& M. Campbell 2013. 'Peacebuilding and Violence against Women: Tracking the Ruling Relations of Aid in a Women's Development NGO in Kyrgyzstan', in A. Choudry and D. Kapoor, eds. NGOization: Complicity, Contradictions and Prospects, London: Zed Books, 185-206.

Korac, M. 2006. 'Gender, conflict and peace-building: Lessons from the conflict in the former Yugoslavia', Women's Studies International Forum 29, 5, 510-520.

Kouvo, S., \& C. Levine 2008. "Calling a spade a spade: Tackling the "women and peace" orthodoxy', Feminist Legal Studies, 16, 3, 363-367.

Martin de Almagro, M. 2016. 'Negotiated Contestation in Peacebuilding: maintaining or transforming systemic narratives?", Critical Studies on Security, 3, 3

MARWOPNET 2015. Website, History. Available online http://www.marwopnet.org/history.htm accessed on 22 August 2015.

Massaquoi, W. 2007. Women and Post-conflict Development: a case study on Liberia. Cambridge: Massachusetts Institute of Technology. http://dspace.mit.edu/bitstream/handle/1721.1/42108/226315252.pdf accessed August 23 2011)

Mazurana, D., Raven-Roberts, A. Parpart, J. \& Lautze, S. 2005. "Introduction: Gender, Conflict, and Peacekeeping," in Mazurana, D., Raven-Roberts, A., \& Parpart, J., eds. Gender, conflict, and peacekeeping. Rowman \& Littlefield Publishers, 1-26.

McLeod, L. 2011. 'Configurations of post-conflict: Impacts of representations of conflict and postconflict upon the (political) translations of gender security within UNSCR 1325', International Feminist Journal of Politics, 13, 4, 594-611.

Medie, P. 2013. 'Fighting gender-based violence: the women's movement and the enforcement of rape law in Liberia' African Affairs 112, 448: 377-397.

Ministry of Gender and Development \& UNIFEM. 2010. Women-based Civil Society Organization (CSO) Directory - Montserrado County 2010 Monrovia: Ministry of Gender and Development and UNIFEM

Mojab, S. 2009. 'Post-war reconstruction, Imperialism and Kurdish Women's NGOs', in N. Al-Ali and N. Pratt, eds. Women and War in the Middle East, London: Zed Books. 99-128.

Moran, M. \& A. Pitcher 2004. "The "basket case" and the "poster child": explaining the end of civil conflicts in Liberia and Mozambique', Third World Quarterly 25, 3: 501-519.

Moran, M. 2009. 'Our Mothers Have Spoken: synthesizing old and new forms of women's political authority in Liberia', Colgate University. http://www.gwu.edu/ igis/assets/docs/Moran_Paper.pdf accessed 14.09.2011.

Norwegian Nobel Committee 2011. 'The Nobel Peace Prize for 2011' Press release, Oslo, October 7, 2011. http://www.nobelprize.org/nobel prizes/peace/laureates/2011/press.html accessed 08.07.2013 
Olonisakin, F., K. Barnes \& E. Ikpe, eds. 2011. Women, Peace and Security. Translating Policy into Practice, London: Routledge.

Otto, D. 1996. 'Nongovernmental organizations in the United Nations system: The emerging role of international civil society', Human Rights Quarterly, 18, 1: 107-141.

Otto, D. 2009. 'The Exile of Inclusion: Reflections on Gender Issues in International Law over the Last Decade', Melbourne Journal of International Law, 10, 1: 11-26.

Pambazuka News 2003. 'Liberia: women call for greater role', 2003-09-04, Issue 122. http://www.pambazuka.org/en/category/wgender/16800/print accessed 22.08.2011.

Pedersen J. 2010. 'Sisters Resist!: women's peace activism in West Africa and North America'. PhD dissertation, Aberystwyth University, Aberystwyth.

Porter, E. 2007. Peacebuilding: Women in international perspective, New York, NY: Routledge.

Pratt, N. \& S. Richter-Devroe 2011. 'Critically examining UNSCR 1325 on women, peace and security', International Feminist Journal of Politics, 13, 4: 489-503.

Reardon, B. A. \& H. Asha, eds. 2010. The Gender Imperative: Human Security vs. State Security, New Delhi: Routledge.

Rehn, E., \& Sirleaf, E. J. 2002. Women war and peace: The independent experts' assessment on the impact of armed conflict on women and womens role in peace-building, New York: UNIFEM. http://ebooks.i2p.us/books/textbooks/Elisabeth\%20Rehn/Progress\%20of\%20the\%20World's\%20Wom en\%202002\%20(786)/Progress\%20of\%20the\%20World's\%20Women\%202\%20\%20Elisabeth\%20Rehn.pdf accessed 17.07.2015.

Roces, M. \& Edwards, L. 2010. Women's Movements in Asia: Feminisms and Transnational Activism, London: Routledge.

Shepherd, L. J. 2008. 'Power and authority in the production of United Nations Security Council Resolution 1325', International Studies Quarterly, 52, 2: 383-404

Shepherd, L. J. 2011. 'Sex, Security and Superhero(in)es: From 1325 to 1820 and Beyond', International Feminist Journal of Politics, 13, 4: 504-521.

Skjelsboek, I., \& D. Smith, eds. 2001. Gender, peace and conflict. London: Sage.

Swaine, A. 2010. 'Assessing the Potential of National Action Plans to Advance Implementation of United Nations Security Council Resolution 1325', Yearbook of International Humanitarian Law, 12: 403-433

Tickner, J. A. 2001. Gendering world politics: Issues and approaches in the post-Cold War era. New York, NY: Columbia University Press.

Tripp, A.M. 2005. 'Women in Movement: Transformations in African political landscapes', in J. Howell and D. Mulligan, eds. Gender and Civil Society: Transcending Boundaries. London: Routledge.

Tripp, A.M., Casimiro, I., Kwesiga, J. And Mungwa, A. 2008. African Women's Movements: Transforming Political Landscapes, Cambridge: CUP. 
Weiss, T. G., \& L. Gordenker 1996. NGOs, the UN, and global governance. Boulder, CO: Lynne Rienner.

Williams, K. 2008. 'Beyond Mass Action: a study of collective organizing among Liberian women using feminist movement perspectives' Brattleboro: SIT Graduate Institute.

Yarrow, T. 2008. 'Life/history: personal narratives of development amongst NGO workers and activists in Ghana', Africa 78, 3: 334-358.

\section{LIST OF INTERVIEWS CITED IN THIS ARTICLE}

Gloria Scott, senator and co-founder and former member of AFELL, Monrovia, 30.06.2011.

Francis Reaves, Representative at the Liberian Congress, 2 September 2013, Monrovia.

'A', senior staff member, Ministry of Gender and Development, Monrovia, 5.07.2011. (Harries)

'B', gender advocate working for an international nongovernmental organization, Monrovia, 27.06.2011. Cerue Konah Garlo IREX

'C', gender advocate working for a Liberian nongovernmental organization, Monrovia, 4.07.2011. Ms

\section{Frances Greaves, Voice of the Voiceless}

'D', representative international donor organization, Monrovia, 28.06.2011. Olga De Biachio

'E', gender advocate working for a Liberian nongovernmental organization, Monrovia, 24.06.2011, Monrovia. Mrs Rosana Schaak, THINK Liberia

'F', gender advocate working for a Liberian nongovernmental organization, Monrovia, 21.06.2011.

Cesaer

'G' gender advocate working for a Liberian nongovernmental organization, Monrovia, 27.06.2011.

Deola

' $\mathrm{H}$ ' gender advocate working for an international nongovernmental organization, Monrovia, 6.07.2011. Williams

'I' president of a national women organisation, Monrovia, 5.09.2013 
'J', gender advocate working for a Liberian nongovernmental organization, Monrovia, 14.08.2013

' $\mathrm{K}$ ' gender advocate working for a Liberian nongovernmental organization, Monrovia, 2.09. 2013

'L' secretary general of a Liberian national women organisation, Monrovia, 19.08.2013

'M' staff member of the Secretariat for the implementation of UNSCR 1325, Ministry of Gender, Monrovia, 15.08.2013.

' $\mathrm{N}$ ' gender advocate from a major Liberian nongovernmental organization, Monrovia, 6.07.2011. Brunell

'O' leader of a local rural women organization in rural Montserrado, 8.08.2013.

'P' gender advocate regional women's organization, Monrovia, 6.07.2011. ECOWAS

'Q' president of a small organisation in rural Montserrado, 7.08.2013

' $\mathrm{R}$ ' president of a national women organization, Monrovia, 3.09. 2013

'S' local staff member from the local country office of an international nongovernmental organization, Monrovia, 8.08. 2013.

' $\mathrm{T}$ ' staff member from the local country office of an international nongovernmental organization, Monrovia, 10.08.2013

\section{NOTES}

\footnotetext{
1 Each interview took approximately eighty minutes. Of the sixty-four interviews, thirty-five belonged to Liberian nongovernmental organizations (NGOs) working on gender equality, eight were government officials or members of parliament working on gender equality, ten were staff members of embassies and international donor organizations and eleven belonged to international nongovernmental organizations (INGOs) working on gender equality. Twelve of the sixty-four interviewees were non-Liberians. Many of the interviewees engaged in peace activism during the war years and its aftermath. It is important to note that the majority of people interviewed were elite, urban-based higher-educated people, with the exception of six activists.
} 
2 Presidential candidate Winston Tubman in an interview with the PRI's The World, October 7, 2011. See http://www.theworld.org/2011/10/liberia-reacts-on-sirleaf-nobel-prize/ (accessed 8 August 2013).

${ }^{3}$ Leymah Gbowee in an interview with BBC radio, 8 October 2012. See http://www.bbc.co.uk/news/world-

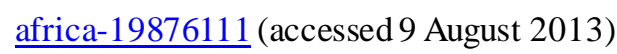

${ }^{4}$ For an account of the specific complexities of social differences and divisions in Liberia and how they have influenced woman's collective activism see Fuest 2009.

5 Leymah Gbowee in an interview with Voice of America, 1 November 2009. See http://www.voanews.com/content/a-13-liberian-women-battle-to-bridge-generation-gap/402677.html (accessed 1 August 2013)

${ }^{6}$ The metaphor was used by several interviewees and refers to a pot of crabs where each crab tries to get out of the pot by pulling down others in a useless king of the hill competition which prevents any crab from escaping and ensures their collective demise.

${ }^{7}$ Participant observation in a meeting of several Liberian women's organizations, 22 June 2011, Monrovia. 